\title{
Development of eCRM Success: A Case Study of Hotel Industry
}

\author{
V. Cherapanukorn
}

\begin{abstract}
In the $21^{\text {st }}$ century, every market has been challenged with the highly competitive environment and the development of innovative information technologies. Hence, customer relationship management (CRM) and the information communication technologies (ICTs) have been focused as one of the important strategies of many industry, as well as hotel industry. However, not all organizations succeed in their eCRM implementation. The main objective of this study was to explore the dimensions of eCRM success in the hotel industry. The advantages of qualitative research approach was applied with a semi-structured questionnaires and five of hoteliers were interviewed. The empirical results showed that there are five main dimensions that lead to eCRM success; include organization readiness, customer service, knowledge management, online communication and technology support. Consequently, this research purposed the eCRM success framework towards the hotel industry context.
\end{abstract}

Index Terms-Hotel, customer relationship management, eCRM, Thailand.

\section{INTRODUCTION}

The concept of customer relationship management (CRM) originates from the notion of customer orientation that not only focuses on customers, but also on the relationships between firms and customers. [1] Moreover, CRM is a sustained strategy for relationship marketing that organizations can use to locate valued customers, which can lead to greater competitive advantage and provide maximum profits for the company. In the 21 st century, the Internet technology has changed customers' behavior, the new electronic communication channel has involved increasing customer satisfaction. Satisfying customer requirements has become more important and been concerned by every business in order to increase their competitive advantages and improve their business performance. Thus, most companies are shifting their focus to customers nowadays by increasing the importance of CRM towards the usefulness of Internet and information communication technologies (ICTS) as a key business strategy. This also transfer CRM implementation to the electronic platform which can been called as electronic customer relationship management (eCRM).

Although many researchers that investigated CRM selectively focused on service sectors, there is still a lack of research into CRM in the hotel and tourism context [2]. In the hospitality industry, a firm's propensity to adopt is a manifestation of its inclination towards innovativeness and its

Manuscript received October 10, 2016; revised February 26, 2017

V. Cherapanukorn is with College of Art Media and Technology, Chiang Mai University, Huaykaew Rd. 239, Suthep, Muang, Chaing Mai, 50200, Thailand (e-mail: vimolboon19@gmail.com). ability to evaluate, accept and use new technologies. Moreover, most hospitality businesses today have developed innovative relationship management program with their customers through online technology. As noted by [3], innovative Internet business models and practices enhance customers' purchasing power, less brand loyalty and is more sophisticated; thus, effective an electronic CRM is becoming an imperative strategy. Especially, in the significant growth of electronic business and the proliferation of Internet-based services, a new concept has been created: electronic customer relationship management (eCRM). It encompasses all the processes needed to acquire, build and maintain customer relationship through e-business and e-commerce application [4].

However, not every organization success in developing relationship with customers [5]. There are no studies that focus on a comprehensive model and framework with interpretation of the empirical relationship between eCRM successful implementation, especially in hotel industry. Therefore, this research proposes a theoretical framework to conceptualize the eCRM success determinants in the hotel industry context.

\section{LITERATURE REVIEW}

\section{A. Customer Relationship Management}

Customer relationship management or CRM is a concept that has developed from relationship marketing theory. The theory of relationship marketing suggests that companies should change their focus from pursuing the aim of selling to the maximum number of people to concentrating on developing relationships with their existing customers [6]. CRM as a strategic approach that enables organizations to use internal resources such as people, processes and technology, to manage their relationships with customers for the entirety of their life cycles, thereby improving an organization's performance and gaining competitive advantage [2].

CRM strategy is focused on the development of a customer-centric business culture dedicated to winning and keeping customers by creating and delivering better value than their competitors [7]. The main focus of CRM is the formation of customer relationships with the intention of improving customer satisfaction and maximizing profits. The study of [8], the CRM concept is also related to user-generated content (UGC), which represents the various forms of content publicly available and created by customers or end-users.

Table I shows that there are three phases in the customer relationship management transaction cycle, which are 
pre-purchase features, at-purchase features and post-purchase features [9]. The relationship between the firms and customers could be developed from the 1st stage through to the last stage.

TABLE I: THREE STAGES OF THE CRM TRANSACTION CYCLE

\begin{tabular}{cl}
\hline \hline Features & \multicolumn{1}{c}{ Actions } \\
\hline $\begin{array}{c}\text { Pre-purchase } \\
\text { (Acquisition) }\end{array}$ & $\begin{array}{l}\text { Promotion/ Incentives Services/ Customer service/ } \\
\text { Direct email }\end{array}$ \\
$\begin{array}{cl}\text { At-purchase } \\
\text { (Retention) }\end{array}$ & Extranets / Personalization / Community/ \\
& Promotions / Loyalty schemes \\
Post-purchase & Direct email/Feedback and complain management/ \\
(Extension) & Onsite promotion/ online community \\
\hline \hline
\end{tabular}

Also significant researches define CRM dimension based on the four factors that leads to CRM success, which include customer orientation, organizational readiness, knowledge management (KM) and information technology based [2], which illustrated in Table II. Furthermore, the restudy by [10] supported that all these factors influence an organization's performance and provide competitive advantage to the firm.

\begin{tabular}{cl}
\hline & TABLE II: CRM DIMENSION \\
\hline \hline Dimension & $\begin{array}{l}\text { Focus on key customer retention, emphasizing } \\
\text { exemplary customer service, or offering superior } \\
\text { products and services to increase customer } \\
\text { long-lasting satisfaction and to develop customer } \\
\text { loyalty. }\end{array}$ \\
\hline Organization & $\begin{array}{l}\text { Focus on top management support, employee } \\
\text { training and motivation, and organizational } \\
\text { structure/processes. The role of the human factor in } \\
\text { the CRM implementation in hotels is fundamental, } \\
\text { because even with the most advanced technology, } \\
\text { people still have a determinant role in managing } \\
\text { customer relationships. }\end{array}$ \\
\hline Knowledge & $\begin{array}{l}\text { Focus on the ability of an organization to capture, } \\
\text { manage and deliver real-time information to } \\
\text { Management }\end{array}$ \\
\hline Information & $\begin{array}{l}\text { Focus on the front-office applications that support } \\
\text { Technology }\end{array}$ \\
\hline \hline & $\begin{array}{l}\text { service, sales and marketing, customer data } \\
\text { repositories and back-office applications. }\end{array}$ \\
\hline
\end{tabular}

\section{B. Electronic Customer Relationship Management}

In these digital ages, CRM has achieved remarkable developments and expanded its applications by using information technology (IT) to integrate sales and services as well as promote a customers' loyalty program [11]. Although the content of electronic customer relationship management (eCRM) is the same as CRM, the implementation method is different [11].

This is because eCRM emphasizes on electronic management, which involves multiple IT systems that place greater focus on efficiency, product image, and personal service value and concurrently fix and analyze the relationships between the firms and their customers. Furthermore, eCRM refers to marketing activities, tools, and techniques delivered over the Internet technologies, such as e-mail, data warehousing and mining, with the specific goal to develop and improve long-term customer relationships in order to enhance their individual potential and business performance [12].
Successful customer relationship management is an important competitive advantage that companies can exploit to prevent consumers from switching to a competitor's company. The need for major effective eCRM implementation is intensified in the e-business environment since customer satisfaction and loyalty are much more difficult to establish in the highly competitive nature of the hotel industry market. Hence, understanding the dynamics of eCRM and assessing its impact on companies' outcomes are crucial [13], especially in the service industry. A study by [14] also proposed the 12 dimension of eCRM for the retail business's website, which can be seen in Fig. 1.

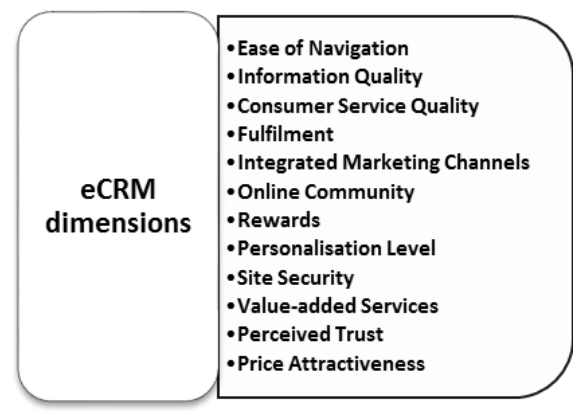

Fig. 1. Twelve Dimensions of eCRM.

\section{C. eCRM Success}

Nowadays, consumers constantly demand careful, continuous and useful communication with company representatives; they can be concerned with their orders, payment method, refund policies and require help with products/ services they have purchased [5]. The main purpose of CRM is to increase the duration of customer satisfaction and to thereby develop customer loyalty, which can ensure a positive impact on a firm's performance [2].

In order to successfully implement eCRM, it is essential to carry out formal organizational change management, which involves a substantial change in business processes and the organization itself [10], which includes a support from top level management team and employees' skills [15]. In addition, to signify higher levels of success in eCRM for internet business, companies need to focus on high levels of improvement in customer satisfaction, transaction amounts and frequency, brand image, efficient business processes, effective database management, technology utilization, and innovation in services that can provide companies with significantly high levels of perceived eCRM success [13].

The research by [5] investigated that the important advantages of successful CRM implementation, such as increased customer loyalty and the development of more effective marketing by retaining and analyzing customers' details. Also, [16] mentioned that eCRM improves understanding of customer behavior and delivering personalized services because of the advantages of Internet-based technology.

Therefore, firms should integrate both technological and marketing elements in order to succeed in eCRM implementation and improve customer satisfaction and loyalty. Furthermore, [17] explained that the internal processes of organizational learning and implementing CRM are divided into four transformations: 1) the process of 
acquiring information about customers; 2) the integration of marketing and IT functions; 3) the involvement of senior management and 4) the employees' evaluation and compensation systems. In addition, the learning experience or knowledge perspective can be regarded as factors for measuring the success of eCRM implementation [13], which can provide benefits to organizations. However, there is still lack of the study that focus on the success dimensions of eCRM implementation in the tourism and hospitality context.

\section{CRM and Internet Technology}

In pursuit of the growth trends and benefits of Web2.0, many hospitality businesses are adopting and profiting from Web 2.0 applications [18]. The study by [19] indicated that among all types of Web 2.0 applications available through the online platform, Blogs have rapidly adopted as a medium channel in travel-related businesses for promoting and communicating their services/products and develop customer relationship.

Web 2.0 technology gives travelers or customers the ability to search and share travel information and experiences through the usefulness of the Internet platform and the concept of user-generated content (UGC) [20]. The use of UGC towards Web 2.0 technology has created a tremendous impact not only on internet users' decision-making, but also on e-business operation which businesses need to be concerned with and adapt to, in order to improve business performance and gain competitive advantages.

Due to benefits of the Internet, Website and social media are used as an innovative channel to communicate with customers. Online promotions and special discount can also be offered to customers as rebates or point redemption in return for repeat purchases or visits [16], which lead to a long-term relationship. Moreover, the advantages of social media technology, such as two-way communication and developing a social network, should be considered by hotels in order to expand their communication channels with customers [5].

A CRM strategy may end in failure if the information technology is not used properly; therefore suitable use and adoption of technology in CRM activities represent one of the greatest opportunities in the hotel industry [21]. Many previous researchers pointed out that a suitable CRM software systems enable firms to offer a customized service with higher quality but at low cost. Thus, the success of many customer-centric activities, like an eCRM strategy, would be impossible without having suitable technology [22]. The CRM technology determinant is strongly related to hotel performance because hotels need to use information technology in order to improve their services and satisfy most customer preferences [5].

Furthermore, trust and site security are another important determinant of the customer relationship. This is because online transactions are associated with perceived risk, confidence and trust in the organization [14], which have become imperative for a customer's decision-making, and has an impact on their loyalty.

With the mentioned above this research aims to explore important dimensions of a successful eCRM implementation and propose the framework of eCRM success towards the hotel context.

\section{RESEARCH METHODOLOGY}

The purpose of this study was exploring the dimensions of electronic customer relationship management towards the hotel industry context; the qualitative approach was applied as the method of this research. The structure of questionnaire was designed based on the major concepts and suggested factors from literatures related to CRM success factors and the internet-based relationship management.

The target population of this research involves hotel practitioners who are from a managerial level and have an experience working regarding customer relationship management for more than 5 years. A sample of this study was selected based on the advantaged of convenient sampling technic. Then, a face to face in-depth interview with the open-ended semi-structured questions was conducted from August to September 2016. A total of 5 hoteliers were interviewed. The data collection process was conducted in Chiang Mai, Thailand, based on the limited of time and budget.

\section{RESEARCH FINDING}

\section{A. Profile of Experts Involved in the Study}

The profiles of all 5 experts involved in this research are shown in Table III. Most of the interviewees are from Front of the house working position such as Sales and Marketing and Room division. A majority of them have had CRM working experience around 6-8 years.

TABLE III: EXPERTS' PROFILE $(N=5)$

\begin{tabular}{|c|c|c|c|}
\hline & & Frequency & Percentage \\
\hline \multirow{3}{*}{ Gender } & Male & 3 & \\
\hline & Female & 2 & \\
\hline & Total & 5 & \\
\hline \multirow{6}{*}{$\begin{array}{l}\text { Educational } \\
\text { Level }\end{array}$} & Vocational Level & 0 & \\
\hline & College & 0 & \\
\hline & Graduated & 3 & \\
\hline & Master & 2 & \\
\hline & Doctor & 0 & \\
\hline & Total & 5 & \\
\hline \multirow{3}{*}{ Position } & General Manager & 1 & \\
\hline & Department Manager & 4 & \\
\hline & Total & 5 & \\
\hline \multirow{6}{*}{ Department } & $\begin{array}{l}\text { General/Administratio } \\
\text { n Office }\end{array}$ & 1 & \\
\hline & Room Division & 1 & \\
\hline & Sales and Marketing & 2 & \\
\hline & Human Resource & 1 & \\
\hline & Management & & \\
\hline & Total & 5 & \\
\hline \multirow{5}{*}{$\begin{array}{l}\text { CRM } \\
\text { Working } \\
\text { Experience }\end{array}$} & $<5$ years & 0 & \\
\hline & $5-7$ years & 2 & \\
\hline & $8-10$ years & 2 & \\
\hline & More than 10 years & 1 & \\
\hline & Total & 5 & \\
\hline
\end{tabular}

After analysis the data from the in-depth interview, the result demonstrated that the important antecedences of eCRM success are covered five main dimensions.

\section{B. Organization Orientation}

The readiness of organization is very important factor to increase eCRM success. It is included the company's vision 
and mission which are focused on a customer-centric approach [15]. The interviewee mentioned that "a customer satisfaction is the main vision and mission of the hotel which is designed from the top managerial level." (Interview respondent no. 2: IR 2) Also, the employees should be trained to have a suitable knowledge and skills regarding customer relationship. For example; "provide a service recovery course for all new staffs and an online customer service training course." (IR 1) Especially, in the digitalization eras, most of the operation processes are transferred to the online systems. Therefore, "it is very necessary for hotels to acknowledge their employees to have a suitable skills and be able to manage customer relation through the online systems." (IR 1)

All hotel staffs should be motivated to satisfy customers and improve their service quality at all times. "Hotel may measure a service preformation of every staff and reward to a person who show the greatest performance." (IR 2) The measurement can be done "twice a year or every three month (quarterly) to maintain a service quality of hotel staffs." (IR 4)

This finding is consistent with a previous study by [2], which examined that the role of the human resource in the eCRM practice in hotels is fundamental, because even with the most advanced technology, people still have a determinant role in managing relationship with customers. The vision and mission from the leader or top management level of the organization is impacted to the firm's structure and employees working characters [2]. Hence, the success of innovative eCRM implementation relies on the active involvement of employees, the leadership and the organizational structure of the firm itself [23].

\section{Customer Service Perspective}

Even through, eCRM is focused the services and relationship development through the online platform, the hotel should understand consumer's personalized requests, have the capacity to handle problems that arise and address consumer complaints in a friendly manner. "Our hotel aims to satisfy all customers' need and we concern every personalize requirement, (IR 4) ...because customers' satisfaction leads to a greater business performance and increase their loyalty." (IR 3) Furthermore, "the hotel tries to deliver a personalize service to every customer and we keep all their special requirements data in our CRM system to make sure that we will provide the best service for them next time when they visit us." (IR 1) Other interviewees also mentioned in the similar idea. These findings are in agreement with a previous research by [16] which claimed that the important success of eCRM implementation is to increase customer loyalty and gain more customer retention by employing all advantaged of the Internet-based technologies.

Moreover, 3 out of 5 interviewees pointed out that "in this globalization era, customers have more choices to choose and their demand have been increased (IR 3), every hotel is challenged to find the technic to keep the loyalty customers such as a membership program, an alliance strategy and other special marketing promotions for loyalty guests. (IR5) Also, IR 4 explained that "our hotel allows customers who already book a room of our hotel to check and view their profile and booking detail, so that they can manage their booking information based on their personal requirements and send all inquiries directly to the hotel."

In addition, "hotel offers a special service to all hotel's guest membership to encourage their retention and develop a long-term relationship between the hotel and a loyalty guest." (IR 3) eCRM improves understanding of customer behavior and delivering personalized services. [16] "Ensuring that customers have a positive experience in the ordering and purchasing processes is also critical in creating a long-term successful relationship." (IR 5) Additionally, an "effective fulfilment of orders' requested is imperative in relationship management, which leads to a positive business outcome." (IR 1) Thus, the hotels should adopt the benefits of internet and computer technologies to understand consumer's special requirements, improve the capacity to handle problems and develop a greater relationship with all customers.

\section{Knowledge Management Prospective}

According to [24], managing knowledge can positively influence to the success of the customer relationship management program. The interviewees also explained that "all staffs are encouraged to share the information and communicate regarding the customer service issue and problems in order to improve the service." (IR 4) because "knowledge sharing from all department is influenced a success of hotel's CRM strategy." (IR 2)

Furthermore, the customer relationship management is linked to the customer knowledge to increase the hotel's service and satisfy more customer's expectations. As the interviewee mentioned that "the hotel encourages all guests to comments regarding the hotel's service by sending e-mail to them or ask them to reply the customer service's survey system," (IR 1) "The hotel can learn and improve the service quality through all guests' feedback." (IR 5)

According to the information from all interviewees, it can be said that a capability in managing knowledge is one factor that organizations should address. This is also in agreement with the study of [25], which stated that knowledge acquisition capability is the ability of a company to capture, manage and deliver real-time authenticated information of products and services to improve customer responses and provide faster decision-making based on reliable information.

Additionally, "the hotel needs to communicate with all agencies both offline and online travel agencies in order to receive and share the information about customers' requirements and comments." (IR 5) Moreover, two of interviewees noted that "the knowledge sharing between hotel and suppliers affects the overall business performance and customer satisfaction," (IR 4) and "the useful information of membership guests that is shared among all alliance hotels through the eCRM system, can help our hotel to increase customer satisfaction and loyalty." (IR 2)

It can be seen that a useful knowledge for CRM is from all sources, both of an internal side (e.g. staffs and organization itself) and an external side (e.g. Suppliers, partners and customers). Therefore, to achieve eCRM success, hotels should consider diffusion of knowledge by encouraging all stakeholders to share knowledge and stimulate acquisition of varied knowledge through transmission between employees 
and suppliers [10]. This also supported by the study of [26] which examined knowledge as one of the main sub-processes of CRM because companies must develop capabilities related to customer knowledge management processes to manage eCRM effectively.

\section{E. Online Communication Perspective}

According to the benefits of the Internet, Website and social media are used as an innovative channel to communicate with customers. "The hotel closely communicates with our customers in order to understand their requirements and special needs through many online platforms." (IR 2) "Our hotel has adopted advantages of social media and the internet to promote our promotion and communicate with all customers." (IR 4) The findings are also supported by related literatures which pointed out that online promotions and special discount can also be offered to customers as rebates or point redemption in return for repeat purchases or visits [16], which lead to a long-term relationship.

Moreover, most of interviewees stated that "the hotel website that is very important channel to communicate with all customers in this high competitive market era." (IR 3 ) "To increase relationship with customers, hotels have to implement not only hotel's website but the hotel have to adopt the advantages of other social media network such as Facebook, Instagram, YouTube and Twitter." (IR 2) These findings are in line with the study by [5] which claimed that the advantages of social media technology, such as two-way communication and developing a social network, should be considered by hotels in order to expand their communication channels with customers

Also, the interviewees noted that "the hotel have to approve and correct every information and content before post up through all online social media platforms." (IR 1) Nonetheless, "every information should be ensured that it is clear and easy to understand" (IR 1) and "ensured that it is up to date all the time to avoid any misunderstanding which may decrease the customer satisfaction." (IR 5)

\section{F. Technology Support Perspective}

Many previous researchers pointed out that a suitable CRM software systems enable firms to offer a customized service with higher quality but at low cost [2]. This is also supported by the information from the interviewee who mentioned that "a suitable of computer software and hardware helps the hotel to improve the CRM implementation." (IR 5) and "all computer systems have to be always updated to the current version...because it can effect to not only CRM implementation but also an overall of the hotel performance." (IR 3)

Therefore, it can be explained that the CRM technology determinant is strongly related to hotel performance because hotels need to use information technology in order to improve their services and satisfy most customer preference [5]. The success of many customer-centric activities, like an eCRM strategy, would be impossible without having suitable technology [22].

Furthermore, trust and site security are another important determinant of the customer relationship. All the interviewees claimed that "the hotel concerns about the customers' trust and security of online transaction," (IR 3) and "a profile of all guests must be secured, (IR 4) the hotel have to consider this as the $1^{\text {st }}$ priority if you aim to increase customer loyalty and success in relationship management." (IR 2) This is because online transactions are associated with perceived risk, confidence and trust in the organization [14], which have become imperative for a customer's decision-making, and has an impact on their loyalty.

\section{CONCLUSION}

Based on the above information, it can be concluded that there are five main dimensions that may significantly influence the success of electronic customer relationship management (eCRM) implementation, which is shown in the following proposed fromework.

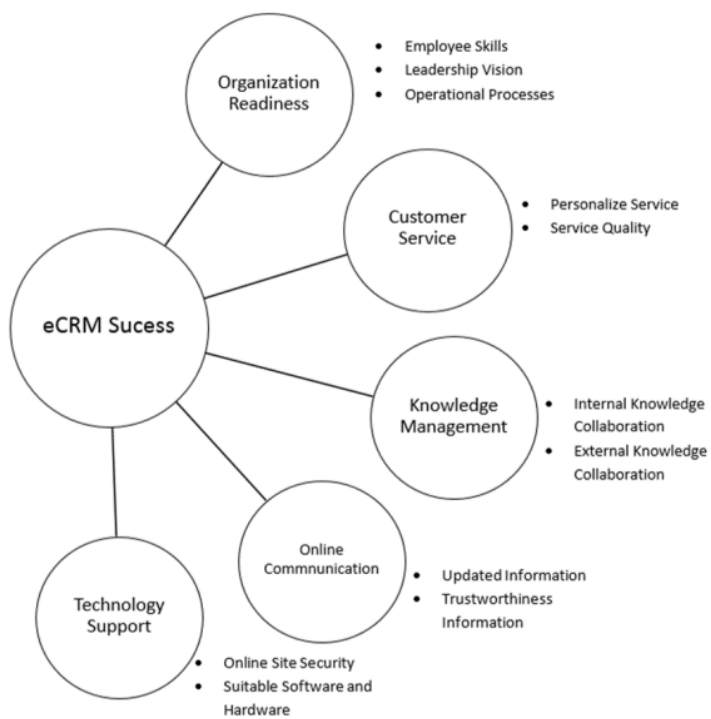

Fig. 2. eCRM success.

In Fig. 2, the framework of eCRM success include five main perspectives; 1) organization readiness perspective, 2) customer service perspective, 3) online communication perspective, 4) knowledge management perspective, and 5) technology support perspective.

The readiness of organizational perspective refers to the top management support, employee training and motivation and organizational processes. To the successful eCRM implementation, hotels need to create should have the right synergy between a vision and strategy from top manager level, business processes and skills of people.

In the customer service perspective, it is focused mainly on the service quality and the ability to deliver personalized service. These directly impact the customer satisfaction and their loyalty which will be influence to the relationship between all customers and the hotel. Hence, to satisfy customers' expectation and achieve a greater eCRM implementation, every hotel should consider towards this dimension.

For the knowledge management perspective, hotels have to focus on the manage information and comments from every staff, then collaborate information to be a useful knowledge of the firm. Furthermore, this dimension is linked to manage and study customers' knowledge from all online platforms in 
order to improve hotel's services and increase customer satisfaction. Therefore, hotels have established knowledge management (KM) programs with all stakeholders, both inside and outside of the organizations, because this dimension is noticed as one of the important key antecedences of eCRM success.

Additionally, the Internet and social network have become a great innovative marketing channel for hotels to promote and communicate with customers and all suppliers worldwide. However, the hotel needs to ensure that all contents are verified and updated, because these can affect customers' satisfaction and their relationship with the hotel.

Furthermore, in the technology support perspective, it is referred to the security of all online processes because it directly impacts not only the customers' loyalty, but also hotel's performance in overall. Moreover, the suitable use and adoption of both hardware and software in eCRM activities represent one of the greatest opportunities in the hotel industry that can decrease a failure implementation in eCRM strategy.

It can be concluded that eCRM is the alternative business strategy which helps hotels to increase the duration of customer satisfaction, develop customer loyalty and achieve a sustainable competitive advantage in the digital competitive marketplace. The success of eCRM implementation is influenced by many important antecedences. In consequence, to accomplish great implementation in eCRM towards these digital decades, hotels and other related businesses should concern in these five dimensions of eCRM success.

Nevertheless, due to the time and budget limitations, this research was studied with only five hotel experts who are working at the five stars hotels in Thailand. To increase the trustworthiness and validity of research results, a further study with wider geographic region and larger sample size is aimed for.

\section{REFERENCES}

[1] S. I. Wu and J. H. Chen, "Comparison between hotels and motels using CRM effect model: An empirical study in Taiwan," International Journal of Hospitality Management, vol. 31, no. 4, pp. 1254-1263, December 2012.

[2] A. A. Mohammed and B. B. Rashid, "Customer relationship management in hotel industry: A framework proposal on the relationship among CRM dimensions, marketing capabilities and hotel Performance," International Review of Management and Marketing, vol. 2. no. 4, pp. 220-230, January 2012.

[3] M. Sigala and E. Christou. (May 2006). Investigating the impact of e-customer relationship management on hotels' website service quality. ECIS 2006 Proceeding. [Online]. pp. 1974-1986. Available: http://aisel.aisnet.org/ecis2006/118

[4] M. Khalifa, and N. Shen, "Effects of electronic customer relationship management on customer satisfaction: A temporal model," in Proc. the 38th Annual Hawaii International Conference on System Sciences, January 2005, pp. 1-10.

[5] M. Sigala, "eCRM 2.0 applications and trends: The use and perceptions of Greek tourism firms of social networks and intelligence," Computers in Human Behaviour, vol. 27, no. 2, pp. 655-661, March 2011.

[6] S. A. Brown, Customer Relationship Management: A Strategic Imperative in the World of e-Business, Ontario, Canada: Tri-Graphic, 2000, ch. 1.

[7] F. Buttle, Customer Relationship Management: Concept and Technologie, Oxford, United Kingdom: Elsevier, 2009, ch.1.

[8] D. H. Park, J. Lee, and I. Han, "The effect of online-consumers reviews on consumer purchasing intention: The moderating role of involvement," International Journal of Electronic Commerce, vol. 11 no. 4, pp. 125-148, 2007.

[9] N. Pechruttanamunee and I. Assenov, "Electronic customer relationship management: Techniques applied, perceived barriers, and future trends in Phuket hotel industry," KKU Journal Graduate Studies, vol. 8, no. 2, pp. 134-142, April-June 2008.

[10] A. Padilla-Meléndez, and A. Garrido-Moreno, "Customer relationship management in hotels: examining critical success factors," Current issues in Tourism, vol. 17, no. 5, pp. 387-396, May 2013

[11] R. H. Chen, R. J. Lin, and P. C. Yang, "The relationships between eCRM, innovation, and customer value-An empirical study," in Proc. 2011 IEEE International Summer Conference of Asia Pacific, Business Innovation and Technology Management (APBITM): IEEE Press, 2011, pp. 299-302.

[12] A. M. Croteau and P. Li, "Critical success factors of CRM technological initiatives," Canadian Journal of Administrative Science, vol. 20, no. 1, pp. 21-34, March 2003.

[13] H. Kimiloglu and H. Zarali, "What signifies success in e-CRM?" Marketing Intelligence \& Planning, vol. 27, no. 2, 246-267, October 2008.

[14] N. R., Ab Hamid, A. W. Cheng, and R. M. Akhir, "Dimensions of E-CRM: An empirical study on hotels' web sites," Journal of Southeast Asian Research, vol. 2, no. 11, pp. 1-15, 2011.

[15] P. Racherla, and C. Hu, "eCRM system adoption by hospitality organizations: A Technology-Organization-Environment (TOE) framework," Journal of Hospitality \& Leisure Marketing, vol. 17, no. 1-2, pp. 30-58, October 2008.

[16] N. R. Ab Hamid, and G. M. McGrath, "The diffusion of Internet interactivity on retail web sites: A customer relationship model," Communication of the IIMA, vol. 5, no. 2, pp. 35-46, 2005.

[17] A. J. Campbell, "Creating customer knowledge competence: Managing customer relationship management programs strategically," Industrial Marketing Management, vol. 22, pp. 375-383, July 2003.

[18] M. Fuchs, C. Scholochov, and W. Hopken, "E-Business adoption, use, and value creation: An Austrian hotel study," Information Technology \& Tourism, vol. 11, no. 4, pp. 267-284, November 2009.

[19] D. Leung, H. A. Lee, and R. Law, “Adopting Web 2.0 technologies on chain and independent hotel websites: A case study of hotels in Hong Kong," Information and Communication Technologies in Tourism 2011, Austria: Springer-Wien, pp. 229-240, 2011.

[20] L. V. Casaló, C. Flavián, and M. Guinalíu, "Understanding the intention to follow the advice obtained in an online travel community," Computers in Human Behavior, vol. 27, no. 2, pp. 622-633, March 2011.

[21] C. Dutu, and H. Halmajan, "The effect of organizational readiness on CRM and business performance," International Journal of Computers, vol. 1, no. 2, pp. 106-114, 2011.

[22] L. Y. M. Sin, A. C. B. Tse, and F. H. K. Yim, "CRM: conceptualization and scale development," European Journal of Marketing, vol. 39, no. 11/12, pp. 1264-1290, 2005.

[23] R. Tamilarasan, 2011, "Customer relationship management in banking services," Journal of Advances in Management, vol. 4, no. 1, pp. 23-34.

[24] M. Xu and J. Walton, "Gaining customer knowledge through analytical CRM,” Industrial Management \& Data Systems, vol. 105, no. 7, pp. 955-972, 2005.

[25] M. Alavi and D. E. Leidner, "Review: KM and KM systems: Conceptual foundations and research issues," MIS Quarterly, vol. 25 no. 1, pp. 107-136, March 2001.

[26] A. R. Zablah, D. N. Bellenger, and W. J. Johnston, "An evaluation of divergent perspectives on customer relationship management: Towards a common understanding of an emerging phenomenon," Industrial Marketing Management, vol. 33, no. 6, pp. 475-489, August 2004.

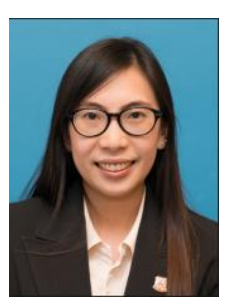

Vimolboon Cherapanukorn is a lecturer and researcher of College of Art Media and Technology, Chiang Mai University, Thailand. She has a bachelor degree in accounting at School of Business and Administration, Chiang Mai University, master of science in international management at University of Exeter, United Kingdom and doctor agree in hotel and tourism management (D.HTM) at School of Hotel and Tourism Management, Hong Kong Polytechnic University, Hong Kong SAR. 